\title{
Ophiolite derived material as parent rocks for Late Jurassic bauxite: evidence for Tithonian unroofing in the Northern Calcareous Alps (Eastern Alps, Austria)
}

\author{
Timotheus Martin Christoph Steiner $^{1}$ (D) Hans-Jürgen Gawlick ${ }^{1}$ (D) Frank Melcher $^{1}$ (D) Felix Schlagintweit $^{2}$ (D)
}

Received: 13 November 2020 / Accepted: 1 May 2021 / Published online: 21 May 2021

(c) The Author(s) 2021

\begin{abstract}
In shallow-water limestones of the Plassen Formation in the Tirolic nappe of the Northern Calcareous Alps, bauxite was formed on karstified and tilted platform margin grainstones to boundstones around the ?Kimmeridgian/Tithonian boundary, or in the Early Tithonian as proven by Protopeneroplis striata Weynschenk, Labyrinthina mirabilis Weynschenk, and Salpingoporella pygmaea Gümbel. The platform established on top of the obducted ophiolite nappe stack. The onset of unroofing at the Kimmeridgian/Tithonian boundary exposed ophiolites to weathering, forming laterites, and bauxites. The weathered ophiolitic material was shed on the tilted, emerged, and karstified platform, where the bauxite accumulated. Continued subsidence led to flooding, and a Tithonian transgressive carbonate sequence sealed the bauxites. XRD analysis of the bauxite yields a composition of mainly boehmite with hematite and some berthierine, kaolinite, and chromite. SEM analysis verified magnetite, hematite, rutile, chromite, zircon, ferropseudobrookite, ilmenite, monazite, xenotime, and garnet distributed in pisoids and within the matrix. The pisoids reach a millimeter in size and partly show cores of older, larger pisoids. The composition of the chromites indicates an ophiolitic origin. Geochemical examination using major- and trace elements points to a mafic andesitic to basaltic parent material contaminated with highly fractionated rocks from an island arc. Formation of Early Tithonian bauxites in shallow-water limestones confirms Middle to Early Late Jurassic ophiolite obduction. This was followed by uplift and unroofing of the orogen from the Kimmeridgian/Tithonian boundary onwards after a period of relative tectonic quiescence with an onset of carbonate platforms during the Kimmeridgian on top of the nappe stack and the obducted Neo-Tethys ophiolites.
\end{abstract}

Keywords Western Tethys $\cdot$ Bauxite $\cdot$ Ophiolite $\cdot$ Jurassic paleogeography

\section{Introduction}

Although considerable work was already done on the geodynamic reconstruction of the Mesozoic-Cenozoic sequence of the Eastern Alps, their geodynamic history, especially in

Timotheus Martin Christoph Steiner

Timotheus.Steiner@gmail.com

Hans-Jürgen Gawlick

gawlick@unileoben.ac.at

Frank Melcher

frank.melcher@unileoben.ac.at

1 Department for Applied Geosciences and Geophysics, Montanuniversitaet Leoben, Peter-Tunner-Str. 5,

8700 Leoben, Austria

2 München, Germany
Late Jurassic times, is not fully understood and controversially discussed (see Gawlick and Missoni 2019 and Schmid et al. 2020 for a comprehensive overview and outlook).

Bauxites are final residues of the continental weathering process and restricted to areas with intense chemical weathering. Recent bauxites formed under conditions of a tropical monsoon climate (Bárdossy and Aleva 1990). This makes bauxites valuable to unravel the geodynamic history as a marker for long-lasting, intense weathering. Longer lasting subaerial exposure can be best explained by tectonic uplift (D'Argenio and Mindszenty 1995). Natural processes like weathering do not entirely terminate or eradicate the affected rocks, and remnants of the parent rocks, at least heavy minerals, can be found in bauxites. The analysis of heavy minerals is a common tool to determine the provenance of the parent material of bauxites. Standard methods of sedimentary provenance analysis (Blatt 1967; Zuffa 
1980; Lewis and McConchine 1994) can also be applied for bauxites and therefore used for hinterland reconstructions. In addition to other siliciclastic components, heavy minerals are especially powerful tools for provenance studies of the original material weathered to bauxites (Kelemen et al. 2017, and references therein).

The Lugberg bauxite, first described by Schadler (1948) and later by Mindszenty et al. (2005), was attributed to the "Mid-Cretaceous" before the Gosauic transgression. This research clarifies the stratigraphic position of the bauxite, provides a reliable dating by examination of the carbonates from the footwall and the hangingwall, and the analysis of heavy minerals in the bauxite to trace the provenance of the weathered ophiolitic parent material.

One of the yet not fully explored problems is the palaeogeographic setting and the evolution of the different isolated platforms of the Plassen Carbonate Platform. In the latest models, at least three platforms with a slightly different evolution were reconstructed and supposed to have formed on top of propagating nappe fronts (Gawlick et al. 2009, 2012; Missoni and Gawlick 2011a, b). These nappe fronts with platforms on top are preserved today as tectonic blocks cutup and scattered by the Late Jurassic, "Mid-Cretaceous", and Miocene tectonics (Frisch and Gawlick 2003). In general, the Plassen Platform has a stratigraphic range from Late Oxfordian/Kimmeridgian to Late Early Berriasian (Gawlick and Schlagintweit 2006; Auer et al. 2009) and evolved from a basinal to slope facies and via a reefal facies to a restricted lagoon with transgressive-regressive cycles. The different platforms did not drown contemporaneously: some drowned in the Late Tithonian, others at the beginning of the Cretaceous (Schlagintweit et al. 2003, 2005; Gawlick and Schlagintweit 2006), and some uplifted in the Late Tithonian (Gawlick et al. 2009 and references therein). This model needs to be slightly modified according to the results of Auer et al. (2010), Krische et al. (2014), and Gawlick et al. (2015). However, there are only few data about the ophiolites of the Neotehyan belt and the unroofing from the alpine realm (Missoni and Gawlick 2011a, b).

In the Northern Calcareous Alps, the rarely existing bauxites are exclusively karst bauxites (Bárdossy 1982; Combes and Bárdossy 1996), i.e., bauxite deposits formed and resting on karstified carbonate rocks. Practically all bauxites are believed to have formed slightly before the Gosauic transgression (Tollmann 1985, 1986 and references therein), i.e., in the "Mid-Cretaceous" (Aptian-Cenomanian) after the main thrusting period in the Early Cretaceous according to the classical concept (Tollmann 1985, 1986; Neubauer et al. 2000; Leitner et al. 2014 and references therein). Late Early Cretaceous tectonic motions are related to the shortening between the Bavaric and Tirolic nappe systems and the effect on the Tirolic nappes is minor (Frisch and Gawlick 2003). The concept to explain the Jurassic tectonics in respect to the (partial) closure of the Neo-Tethys (Lein 1985; Gawlick et al. 1994, 1999a) is still rarely used, although the alternative nappe concept presented by Frisch and Gawlick (2003) solved numerous unsolved questions. Later, Missoni and Gawlick (2011a, b) and Gawlick et al. (2015) proved ophiolite obduction as known from the Dinarides/Albanides/ Hellenides (Gawlick et al. 2008; Schmid et al. 2008) as the triggering mechanism of Middle/Late Jurassic thrusting also for the Northern Calcareous Alps. For a recent overview, see Gawlick and Missoni (2019) and Schmid et al. (2020). The configuration of the ophiolitic nappe stack in the eroded southern Calcareous Alps and the formation of a Kimmeridgian-Tithonian carbonate platform on top (similar to what is known in the Albanides as shown by Schlagintweit et al. 2008) and its subsequent uplift and erosion in the frame of mountain uplift and unroofing in the Tithonian like proven in the Dinarides/Albanides/Hellenides (Gawlick et al. 2020 for a recent review) is still relatively unknown and existing reconstructions of this realm based on pebble analysis in the different resediments (Missoni and Gawlick 2011a, b). The discovery of bauxites in Tithonian shallow-water carbonates and their provenance from obducted and weathered ophiolites closes an important knowledge gap in the geodynamic history of the Northern Calcareous Alps.

In comparison with the evolution of the known Late Jurassic carbonate platforms in the Northern Calcareous Alps, Mt. Lugberg shows differences, which do not strictly allow to assign the succession to any of the time-equivalent platforms. The northernmost Wolfgangsee Carbonate Platform shows an evolution with prograding reefs during Kimmeridgian Tithonian times and a Late Tithonian drowning. The Plassen Carbonate Platform s. str. in a central position started to evolve in the Early Kimmeridgian and drowned in the Late Berriasian. From the Plassen Platform s.str. Late Kimmeridgian to Early Tithonian transgressive-regressive cycles are described (Schlagintweit et al. 2005; Schlagintweit 2011). The southern Lärchberg Carbonate Platform differs only slightly in the sedimentary evolution and evolved during the Kimmeridgian-Tithonian timespan and uplifted in the latest Tithonian. Bauxite is not known from any of the platforms. Equivalents from a more southern carbonate platform formed on top of the obducted Neo-Tethys ophiolites, as known from Greece (Carras et al. 2004), Albania (Schlagintweit et al. 2008), or Serbia (Gawlick et al. 2020 and references therein) were so far not detected in the Eastern Alps. Late Jurassic shallow-water components associated with ophiolitic detritus in the Kimmeridgian (Missoni and Gawlick 2011a, b; Gawlick et al. 2015) may have derived from this platform, but a direct proof for the existence of an equivalent of the Kurbnesh Platform (Schlagintweit et al. 2008) is still missing.

The recent discovery of the Lugberg bauxite provides further important data for a more detailed reconstruction of 
Late Jurassic geodynamic history of the eroded southern rim of the Northern Calcareous Alps after ophiolite emplacement and their overlying Kimmeridgian-Tithonian shallowwater carbonate platform.

\section{Geological setting}

The Lugberg bauxite deposit is located halfway between Russbach and the Schwarzensee lake in Upper Austria at the WGS 84 coordinates $47^{\circ} 44^{\prime} 36.7^{\prime \prime} \mathrm{N} 13^{\circ} 30^{\prime} 34.1^{\prime \prime}$ E. Here, the bauxite crops out at the rims of an unusually wet meadow (Fig. 1).

The Late Jurassic Plassen Limestone of Mt. Lugberg is interpreted as a part of the Wolfgangsee Carbonate Platform (Gawlick et al. 2007) that differs in its general sedimentary evolution from other Plassen Carbonate Platforms. Here, shallow-water formation started in the Early Kimmeridgian and ended in the Late Tithonian by drowning. The Wolfgangsee Carbonate Platform is predominantly composed of fore-reefal and reefal limestones. In contrast to the Plassen Carbonate Platform s. str. (Schlagintweit et al. 2003) or the Lärchberg Carbonate Platform (Gawlick et al. 2009), here thick lagoonal limestones are missing. However, the small northeastern part of Mt. Lugberg hosting the bauxites consists of platform margin (upper slope) Plassen Limestone underlain by ooidal grainstones and is separated by an ancient fault containing ophiolitic mélange from the rest of the Wolfgangsee Carbonate Platform and presumably has a different palaeogeographic origin. On a large scale, Mt. Lugberg is located in the Tirolic unit just north of the Wolfgangsee fault (Plöchinger 1964, Fig. 2).

\section{Materials and methods}

A Panalytical X'Pert3 Powder Diffractometer with a $\mathrm{Cu}$ anode measuring from $0^{\circ}$ to $90^{\circ}$ was used for XRD measurements. Actlabs performed the chemical analyses with the packages 4E-Res + ICPMS, or 4LITHO 4B-INAA(4B) 4B1, respectively. The SEM measurements were taken with a Zeiss Evo MA 10 operated at $15 \mathrm{kV}$ with a Bruker EDX detector. The geochemical analysis was performed using the statistical software R with the GCDkit (Janoušek et al. 2006); image analysis was performed with ImageJ using Fiji (Schindelin et al. 2012).

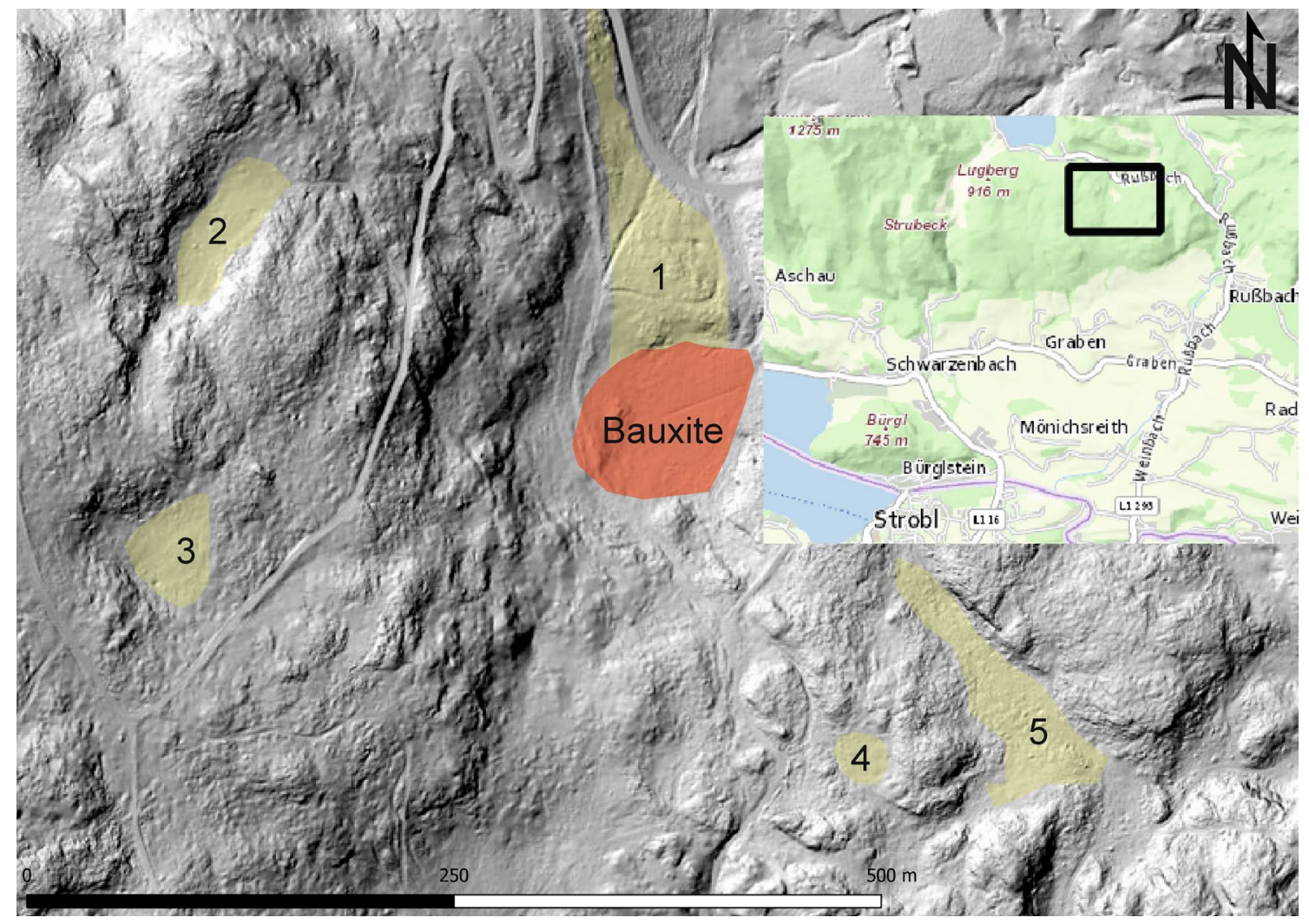

Fig. 1 Airborne laser scan image of the bauxite bearing area of the Lugberg with the bauxite occurrence. The areas marked in yellow numbered 1-5 are outcrops of the siliciclastics covering the bauxite 

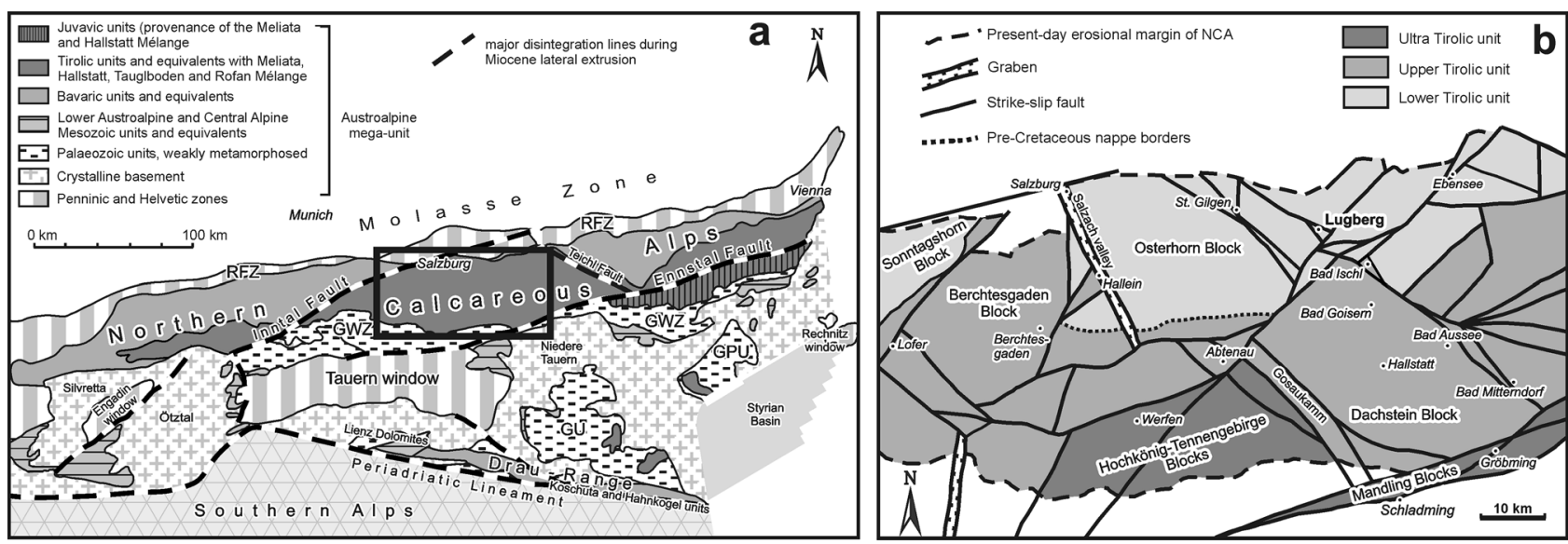

Fig. 2 a Tectonic sketch map of the Eastern Alps and study area (marked by the thick-lined box; b) in the central Northern Calcareous Alps (modified after Frisch and Gawlick, 2003, and Tollmann, 1977). GPU Graz Paleozoic unit; $G U$ Gurktal unit; GWZ Greywacke Zone; RFZ Rhenodanubian Flysch Zone. b Recent block configura-

\section{Results}

\section{Bauxite}

Examination of the powdered bauxite by XRD (Fig. 3) yielded boehmite as the main mineral; minor minerals are berthierine, hematite, some kaolinite, and some chromite. No mixed-layer clay minerals were detected; therefore, the sample was not treated for further examinations. This is tion of the Tirolic nappes in the central Northern Calcareous Alps with major faults during Miocene lateral tectonic extrusion (simplified after Frisch and Gawlick 2003). Studied locality Lugberg indicated in bold

consistent with the results of Mindszenty et al. (2005), although they also found plagioclase.

SEM analysis and microscopy yielded rutile, chromite, zircon, ferropseudobrookite, ilmenite, monazite, and garnet as heavy minerals. The bauxite is rich in $\mathrm{Fe}_{2} \mathrm{O}_{3}$ and magnetite and hence shows macroscopically magnetic properties. $\mathrm{Fe}_{2} \mathrm{O}_{3}$ could be present as hematite or maghemite, a distinction is not possible by SEM analysis, however, XRD analysis only prove hematite. The pisoids, in some cases, have a core of broken older, even larger pisoids (Fig. 4a, b) and

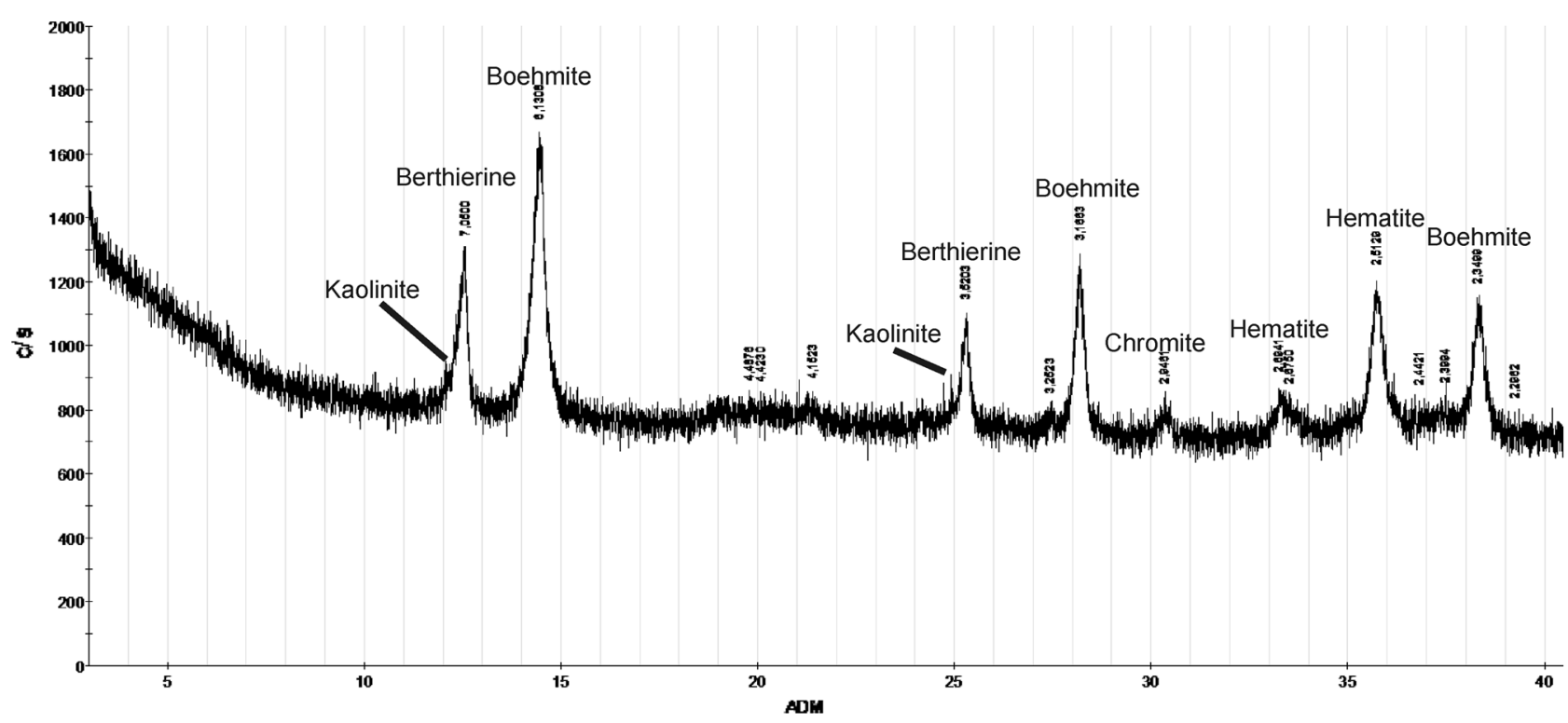

Fig. 3 XRD spectrum of the Lugberg bauxite. The boehmite, berthierine, and hematite peaks are clearly visible; the kaolinite and the chromite peaks are relatively small but distinct 

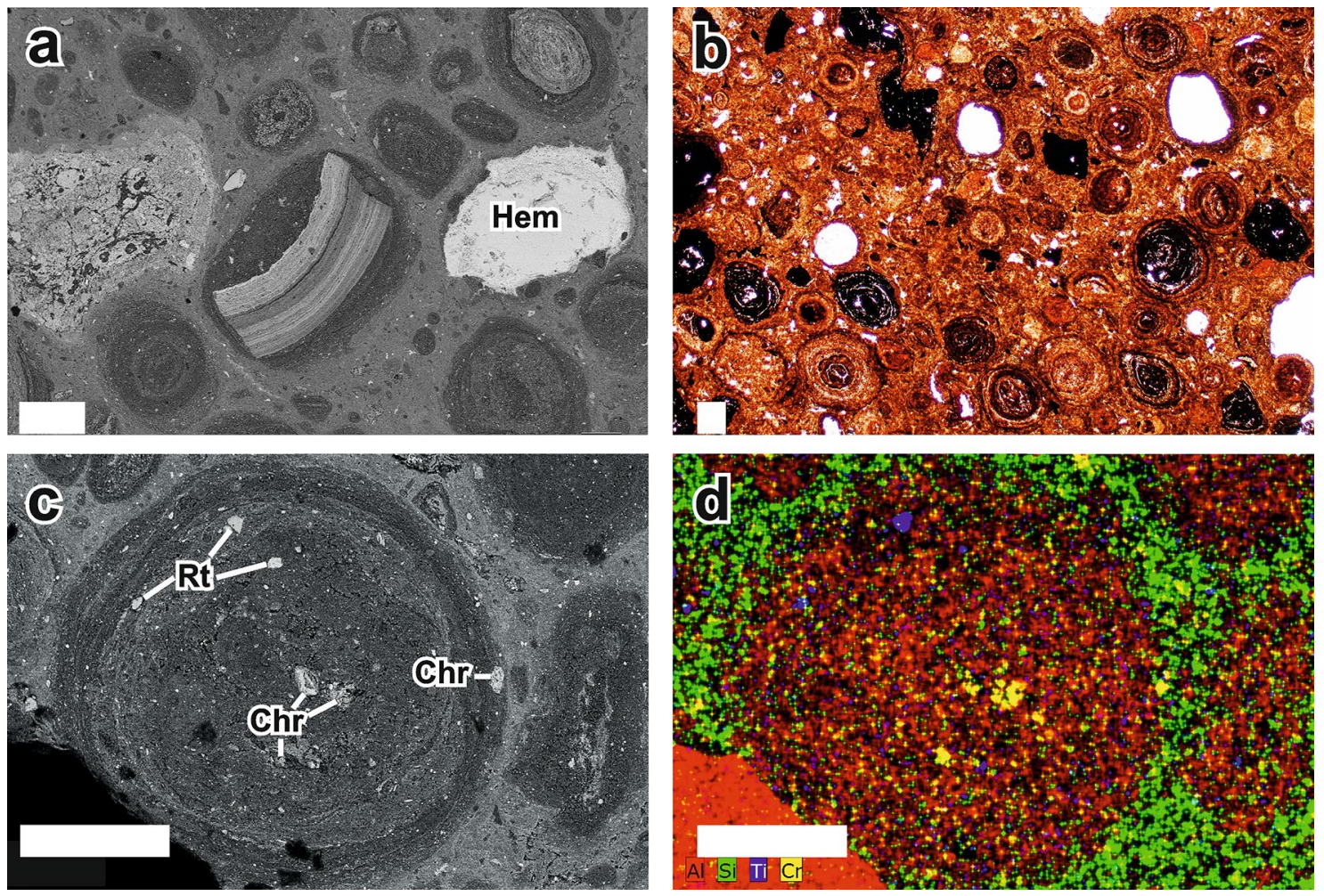

Fig. 4 a Sedimentological features of the Lugberg bauxite; an overview image of the Lugberg bauxite comprising large pisoids, some of them with broken fragments of older pisoids as cores and hematite (Hem) concretions; b similar image in transmitted light; c pisoid con-

are often enriched in clastic grains in the core. The pisoids are enriched in $\mathrm{Al}$ with respect to the matrix (Fig. 4c, d) but are sometimes entirely composed of hematite (Fig. 4c). Frequent clasts in pisoids are rutile and ilmenite, whereas chromite and zircon are rare. Chromite is often rounded. Magnetites have broadly varying amounts of $\mathrm{Al}, \mathrm{Mg}$, and $\mathrm{Cr}$ (each up to 10 atomic percent) and probably formed as alteration product from chromite either by serpentinization (when present as clastic grains) or during the bauxitisation (when present as spongy structures often intergrown with hematite, Fig. 5a). Heavy mineral grains can be found both in the matrix and in the pisoids, although rutile and chromite tend to concentrate in the pisoids while zircon and xenotime are more frequent in the matrix. As an accessory mineral, xenotime carrying REE contents was observed (Fig. 5b).

\section{Microfacies of the Plassen limestone}

The footwall of the bauxite comprises ooidal grainstones (Fig. 6a). The bauxite is hosted by karst depressions in the ooidal grainstones and is partly eroded. Deep bauxitic infiltrations in the ooidal grainstones underlying the bauxite are common (Fig. 7). The under-ore breccia comprises $\mathrm{cm}$-sized angular to subangular clasts of the underlying limestones as

taining clasts of rutile (Rt) and chromite (Chr); d Same image as c as element map, note the pisoids enriched in $\mathrm{Al}$ and the matrix enriched in Si. All scale bars are $200 \mu \mathrm{m}$

well as Plassen Limestones with a bauxitic matrix (Fig. 6b, for bulk analysis, see Table 1). Directly above the bauxite follows a siliciclastic silty sand layer overlain by carbonates. The siliciclastic unit crops out over a far larger area than the bauxite (Fig. 2). The carbonates above start with finegrained packstones with small foraminifers (Fig. 6c), above follow platform margin (upper slope) Plassen Limestones (Fig. 6d). The Plassen Limestones comprise grainstones and boundstones with abundant dasycladales, crinoids, foraminifers, bivalves, gastropods, and encrusting organisms [mainly Crescentiella morronensis (Crescenti)].

\section{Biostratigraphy of the Plassen limestone}

Typical, but not exactly datable platform margin (upper slope) sediments of the Plassen Formation form the hangingwall of the bauxite. The following microfossils were found (Fig. 7): Radiomura cautica (Senowbari-Daryan and Schäfer), Crescentiella morronensis (Crescenti), Protopeneroplis striata (Weynschenk), Labyrinthina mirabilis (Weynschenk), and Salpingoporella pygmaea (Gümbel), Neuropora lusitanica (Termier and Termier). The first two taxons point to a reef near position. In the Plassen Formation, $P$. striata has a stratigraphic range from Kimmeridgian 

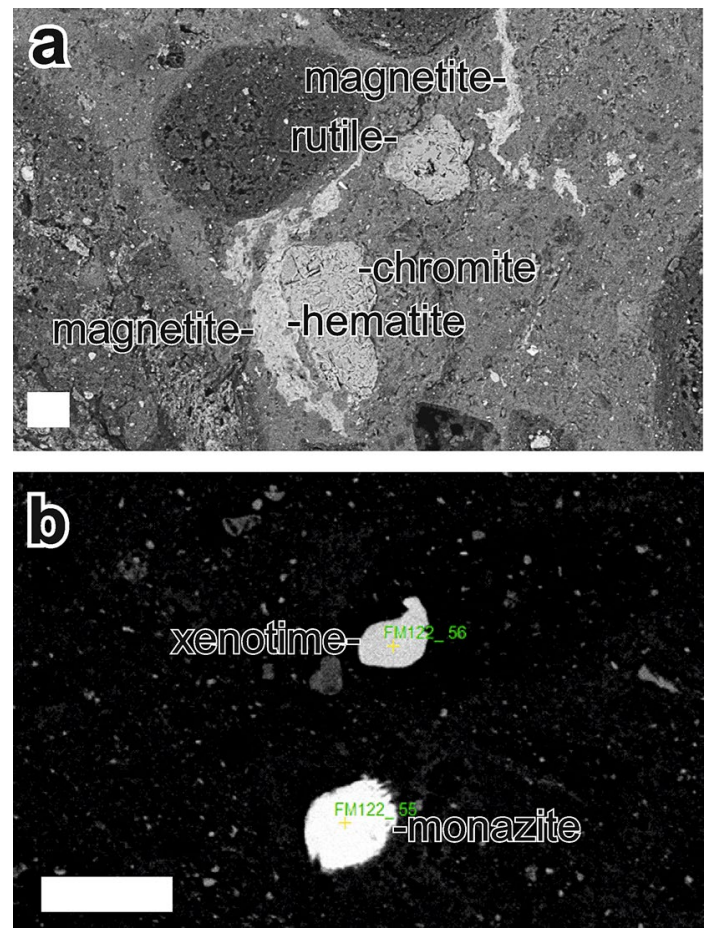

Fig. 5 a Rutile and chromite grains; magnetite and traces of hematite are authigenic formations in the matrix; b Two REE-mineral grains, the lower is monazite-(Ce, La), the upper is xenotime-(Y, Dy). The scale bar is $20 \mu \mathrm{m}$

to Upper Tithonian, L. mirabilis has a stratigraphic range from Upper Kimmeridgian to Lower Tithonian, and S. pygmaea has a stratigraphic range from Upper Kimmeridgian to Lower Berriasian (Schlagintweit et al. 2005). Hence, the hanging wall of the bauxite can be dated as Late Kimmeridgian to Lower Tithonian, most likely Early Tithonian. The direct footwall consisting of ooidal grainstones is not possible to date, but as the under-ore breccia contains Plassen Limestone pebbles it can be dated as Kimmeridgian, as it is older than the hanging wall and the oldest known Plassen Limestone is of Early Kimmeridgian age.

\section{Geochemistry}

Determining the dominant parent rock is possible using the FMW diagram (Ohta and Arai 2007, Fig. 8a) and comparing the dataset with several other proxies relying on normalized ratios of immobile trace elements. The FMW diagram is the result of a principal component analysis of chemical data of igneous rocks and their weathering profiles. The result indicates two principal components covering $\sim 75 \%$ of the total variability, which can be used to construct the FMW triangle. F represents the felsic component, $\mathrm{M}$ represents the mafic component, and $\mathrm{W}$ is the superimposed weathering component (Ohta and Arai 2007). The data of the bauxite plots directly on the right sideline of the FMW diagram, the composition of the parent material was most likely at least andesitic_-if not basaltic. This is in accordance with the $\mathrm{Nb} / \mathrm{Y}-\mathrm{Zr} / \mathrm{Ti}$ plot (Winchester and Floyd 1977 modified by Pearce 1996, Fig. 8b), pointing to an andesitic bulk parent rock composition. If some highly fractionated material contaminated the presumably basic main contributing material, the result would still have a basic bulk composition in terms of the main elements, but the trace element composition would be shifted noticeably towards the fractionated material. This is exactly what can be observed in the Lugberg samples.

The Nb-Zr-Y diagram (Meschede 1986, Fig. 8c), the La/10-Y/15-Nb/8 plot (Cabanis and Lecolle, 1989, Fig. 8d), and the geotectonic diagram for (ultra-)basic rocks used for tectonic discrimination of basalts (Agrawal et al. 2008, Fig. 8e) are in accordance and point to a source material derived from an oceanic island arc formed in a compressional setting. The multi-element spider diagram normalized to mid-ocean ridge basalt (MORB, Dilek and Furnes 2011) points to a supra-subduction zone (SSZ) origin of the bauxite with a boninitic contribution.

\section{Chromites}

The Lugberg spinels can be divided (compare Fig. 4a) into comparatively fresh and altered former chromites. Fresh grains are compact and rounded; altered grains often have irregular shapes and a high compositional variability. The fresh grains are chromites and Al-chromites, while the altered grains are $\mathrm{Al}, \mathrm{Mg}$, and $\mathrm{Cr}$ bearing magnetites. $\mathrm{Al}$, $\mathrm{Cr}, \mathrm{Mg}$, and $\mathrm{Ti}$ contents of chromites can be used to determine the tectonic provenance. The model of Kamenetsky et al. (2001) uses Ti and Al for discrimination. Aside from major outliers, which were recognized as altered grains, most grains plot in the fields of SSZ peridotite and MORB peridotite (Fig. 9a). The discrimination chart of Pearce et al. (2000) plots the $\mathrm{Cr} \#$ versus the $\mathrm{TiO}_{2}$ content of the spinels (Fig. 9b). The lower-left of the diagram illustrates the calculated melting trend of fertile MORB mantle. From the differently depleted mantle rocks, the lherzolite and the dunite reactions originate. The lherzolite reaction is typical for the chemical evolution of a MORB. The dunite reaction is typical for the chemical evolution of SSZ melts. Boninites form from high rates of partial melting of depleted mantle under the influence of dehydration of the subducting slab (Johnson 2012). Island arc tholeiites represent melts formed from less depleted mantle material (Johnson 2012). The chromites plot in the range of the dunite reaction field pointing to boninites and island arc tholeiites as host rocks. One chromite has a less Cr-rich composition close to the depleted mantle array. This confirms that the chromites originated in a SSZ setting consistent with the result of the whole rock geochemistry. 

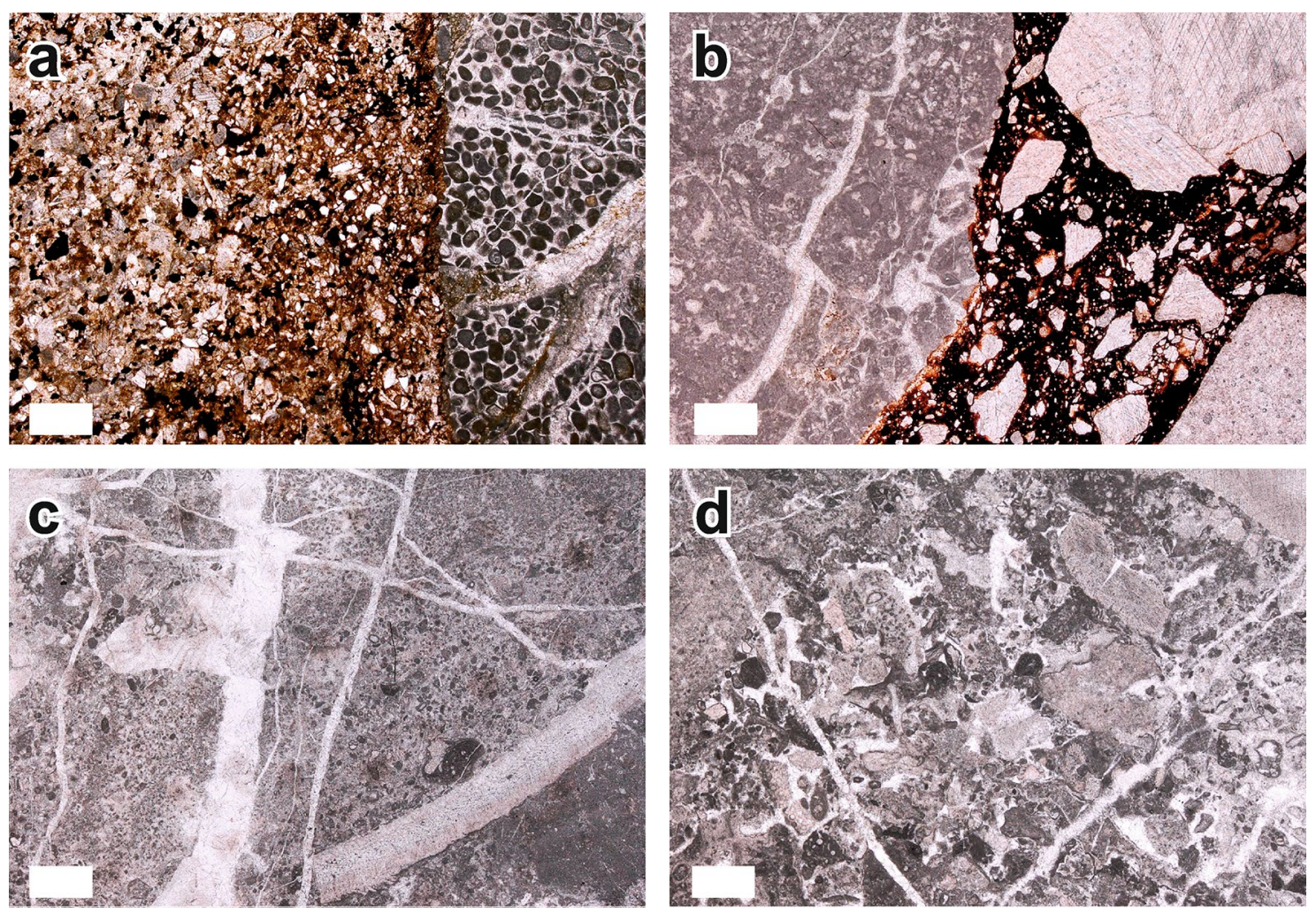

Fig. 6 Microfacies of the Late Jurassic Plassen Formation in the surrounding of the bauxite outcrops; a ooidal grainstone with bauxitic infiltration; b Under-ore breccia of the central part with fresh and recrystallized fragments of Plassen limestone; c Fine-grained trans-

gressive limestone with fragments of decapod crab shells; $\mathbf{d}$ platform margin (upper slope) Plassen Limestone: grainstone with crinoids and encrusting organisms. The scale bar is $1 \mathrm{~mm}$

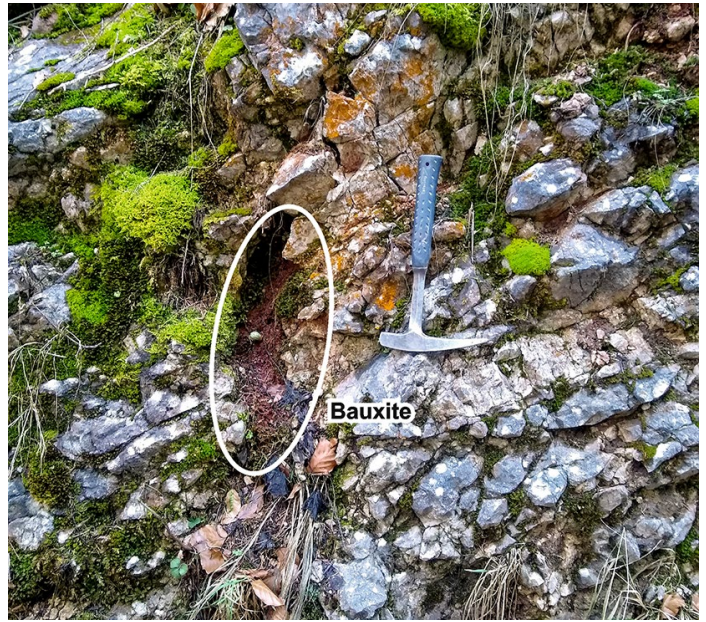

Fig. 7 The ooidal grainstones below the bauxite. Circled is a large bauxite-bearing infiltration

\section{Discussion}

The provenance of the pre-bauxitic material deposited on karstified platforms is controversially discussed in the literature (Bárdossy 1982; Combes and Bárdossy 1996; Marković 2002; Pajović et al. 2017). Silicate material (clay) intercalated in such carbonates, volcanic ashes, and/or other windblown material generally was used to explain the formation of karst bauxites as in situ weathering products (Bárdossy 1982; Combes and Bárdossy 1996; Muhs et al. 2012). Exposed platform carbonates providing the karstified surfaces on which karst bauxites occur are extremely poor in clay minerals often thought to be possible sources for bauxites. Nevertheless, volcanic ashes might be alternative sources, and thick Early Tithonian volcanic ash layers are also known in the Northern Calcareous Alps (Gawlick et al. 1999b). However, in contrast to the widely favored model of 
Table 1 Analytical data of the Lugberg bauxite and the under-ore breccia

\begin{tabular}{|c|c|c|c|c|c|c|c|c|c|}
\hline Analyte & Unit & Analytical method & Bauxite & under-ore breccia & Analyte & Unit & Analysis Method & Bauxite & $\begin{array}{l}\text { Under- } \\
\text { ore } \\
\text { breccia }\end{array}$ \\
\hline $\mathrm{SiO}_{2}$ & $\%$ & FUS-ICP & 12.78 & 5.45 & Gd & ppm & FUS-MS & 28.8 & 2.82 \\
\hline $\mathrm{Al}_{2} \mathrm{O}_{3}$ & $\%$ & FUS-ICP & 45.46 & 4.97 & $\mathrm{Ge}$ & ppm & FUS-MS & 2 & 0.5 \\
\hline $\mathrm{Fe}_{2} \mathrm{O}_{3}(\mathrm{~T})$ & $\%$ & FUS-ICP & 25.47 & 4.37 & $\mathrm{Hf}$ & ppm & FUS-MS & 13.9 & 1.7 \\
\hline $\mathrm{MnO}$ & $\%$ & FUS-ICP & 0.045 & 0.024 & $\mathrm{La}$ & ppm & FUS-MS & 183 & 14.2 \\
\hline $\mathrm{MgO}$ & $\%$ & FUS-ICP & 1.22 & 0.4 & $\mathrm{Lu}$ & ppm & FUS-MS & 2.39 & 0.183 \\
\hline $\mathrm{CaO}$ & $\%$ & FUS-ICP & 0.09 & 46.36 & $\mathrm{Nb}$ & ppm & FUS-MS & 45 & 4.5 \\
\hline $\mathrm{Na}_{2} \mathrm{O}$ & $\%$ & FUS-ICP & 0.02 & $<0.01$ & $\mathrm{Nd}$ & ppm & FUS-MS & 138 & 15.3 \\
\hline $\mathrm{K}_{2} \mathrm{O}$ & $\%$ & FUS-ICP & 0.03 & 0.03 & $\mathrm{Ni}$ & ppm & TD-ICP & 802 & 20 \\
\hline $\mathrm{TiO}_{2}$ & $\%$ & FUS-ICP & 2.177 & 0.251 & $\mathrm{~Pb}$ & ppm & TD-ICP & 90 & 12 \\
\hline $\mathrm{P}_{2} \mathrm{O}_{5}$ & $\%$ & FUS-ICP & 0.17 & 0.03 & $\operatorname{Pr}$ & ppm & FUS-MS & 35.3 & 3.72 \\
\hline LOI & $\%$ & GRAV & 12.75 & 38.02 & $S$ & $\%$ & TD-ICP & 0.008 & 0.004 \\
\hline Total & $\%$ & FUS-ICP & 100.2 & 99.92 & $\mathrm{Sc}$ & ppm & FUS-ICP & 56 & 8.04 \\
\hline As & $\mathrm{ppm}$ & INAA & 20.8 & 5 & $\mathrm{Sm}$ & ppm & FUS-MS & 27.7 & 3.03 \\
\hline $\mathrm{Ba}$ & ppm & FUS-ICP & 105 & 14 & $\mathrm{Sr}$ & ppm & FUS-ICP & 27 & 40 \\
\hline $\mathrm{Bi}$ & $\mathrm{ppm}$ & FUS-MS & 0.9 & 0.1 & $\mathrm{Ta}$ & ppm & FUS-MS & 3.3 & 0.32 \\
\hline $\mathrm{Ce}$ & ppm & FUS-MS & 219 & 27.3 & Th & ppm & FUS-MS & 38.5 & 5.98 \\
\hline $\mathrm{Co}$ & ppm & INAA & 75 & 3.2 & $\mathrm{U}$ & ppm & FUS-MS & 6.9 & 1.12 \\
\hline $\mathrm{Cr}$ & ppm & INAA & 2990 & 71.9 & V & ppm & FUS-ICP & 310 & 74 \\
\hline $\mathrm{Cu}$ & ppm & TD-ICP & 32 & 3 & W & ppm & FUS-MS & 7 & $<1$ \\
\hline Dy & $\mathrm{ppm}$ & FUS-MS & 27.6 & 2.31 & $\mathrm{Y}$ & ppm & FUS-ICP & 240 & 14 \\
\hline $\mathrm{Er}$ & $\mathrm{ppm}$ & FUS-MS & 17 & 1.3 & $\mathrm{Yb}$ & ppm & FUS-MS & 15.6 & 1.24 \\
\hline $\mathrm{Eu}$ & $\mathrm{ppm}$ & FUS-MS & 6.23 & 0.687 & $\mathrm{Zn}$ & ppm & TD-ICP & 68 & 14 \\
\hline $\mathrm{Ga}$ & ppm & FUS-MS & 56 & 12 & $\mathrm{Zr}$ & ppm & FUS-ICP & 502 & 60 \\
\hline
\end{tabular}

wind-blown material as source for bauxites (Pajović 2000, 2009), the source material for the Lugberg bauxite was more likely transported by surface waterflows: the grain size of the resedimented material (the largest single heavy mineral grains reach $200 \mu \mathrm{m}$ ) excludes long-distance wind transport in a climate suitable for bauxite formation. Additionally, long-distance wind transport would produce a geochemistry similar to loess instead of the observed pattern.

This bauxite can be therefore classified as a parautochthonous to allochthonous bauxite according to the classification of Combes and Bárdossy (1996).

The heavy minerals and their geochemistry, and the transportation of pre-bauxitized material, including slightly older broken pisoids, led to the following reconstruction of the area where the Lugberg bauxite developed: Uplift and unroofing started around the Kimmeridgian/Tithonian boundary (Missoni and Gawlick 2011a, b; Gawlick and Missoni 2019; Gawlick et al. 2020) the time frame of the bauxite formation-and uplift movements affected mainly the obducted ophiolites with the platform on top (equivalent to the Kurbnesh platform in Albania: Schlagintweit et al. 2008) and the Lärchberg Carbonate platform (Figs. 10, 11). Uplift of the orogen caused local extension and block tilting.
Traces of such a platform with very similar facies and microfossils are documented by Gawlick et al. (2020) in the Dinarides in basinal sediments, and it can be assumed that mount Lugberg is the first occurrence of this platform type in the Eastern Alps. Based on these results, the formation of the Lugberg bauxite can be reconstructed as follows:

- In the Kimmeridgian, carbonate platforms formed in front and on top of the propagating ophiolite nappe stack (Fig. 10c). The equivalent of this southeasternmost carbonate platform in the Eastern Alps is the Kurbnesh Platform on top of the Mirdita ophiolites (Albania; Schlagintweit et al. 2008), to the northwest follows the Lärchberg Carbonate Platform (LCP).

- At the Kimmeridgian/Tithonian boundary, unroofing started with uplift in the south, exposing ophiolites to weathering (Fig. 10d) under tropical climatic conditions suitable for the carbonate platforms to flourish and inducing bauxite formation. At the same time on the exposed ophiolites, deep weathering resulted in lateritisation, and probably even bauxitisation comparable to nowadays Haiti (Boulègue et al. 1989). Under such conditions, bauxite-minerals may form in time intervals of even 

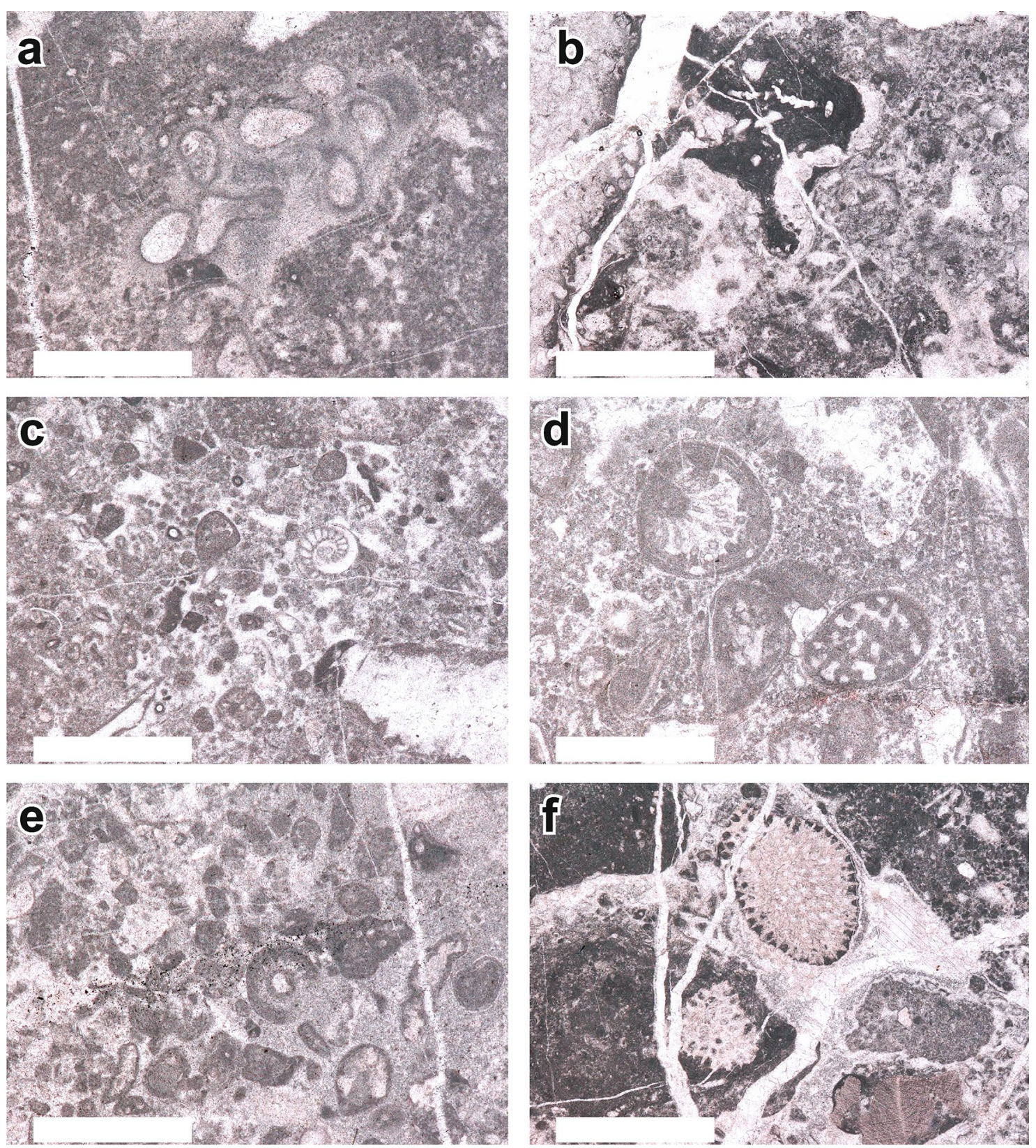

Fig. 8 Microfossils from the hanging wall of the bauxite a Radiomura cautica (Senowbari-Daryan and Schäfer); b Crescentiella morronensis (Crescenti); c Protopeneroplis striata (Weynschenk); d

Labyrinthina mirabilis (Weynschenk) (right below) and Salpingoporella pygmaea (Gümbel) (left); e Salpingoporella pygmaea (Gümbel); f Neuropora lusitanica (Termier and Termier). The scale bar is $1 \mathrm{~mm}$

10.000 years (Valeton 1972), while their accumulation to form bauxite is possible within 100.000 years (Boulègue et al. 1989) leaving enough time for the accumulation of bauxite on the emerged platform.

- Ongoing unroofing affected the carbonate platforms resulting in block tilting, karstification, and shedding of weathered ophiolitic material on the platforms (Fig. 10d). The ooidal horizon below the bauxite represents the shallow-water conditions just before the emergence of the

platform. The formation of the bauxite may have been short-lasting, as the bauxite was already pre-weathered, and not much time for the final bauxitization is needed. This is also supported by the occurrence of numerous transported broken large pisoids.

- Continued subsidence led to flooding of the bauxite deposit indicated by the transgressive sequence sealing the bauxite deposit (Fig. 10e). 

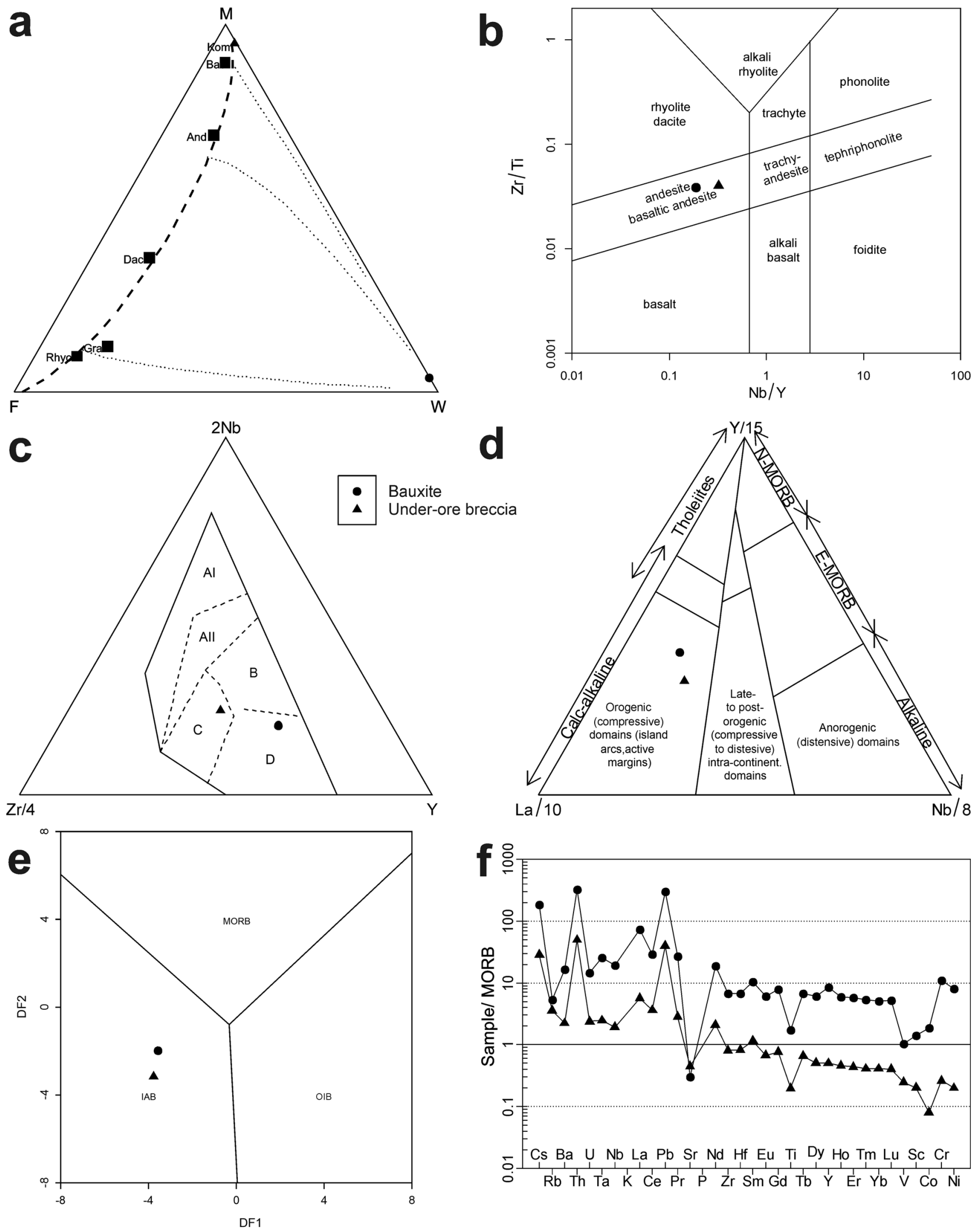
4Fig. 9 a FMW diagram (Ohta and Arai 2007) with both samples plotting on the right sideline of the triangle indicating a basic-mafic protolith, Rhyo rhyolite, Gra granite, Dac dacite, And andesite, Bas basalt, Kom Komatiite; b Nb/Y-Zr/Ti plot (Winchester and Floyd 1977 modified by Pearce 1996) for magma discrimination using immobile elements; c Nb-Zr-Y diagram (Meschede 1986), abbreviations: AI, AII $=$ within-plate alkaline basalts; AII, $\mathrm{C}=$ within-plate tholeiites; $\mathrm{B}=\mathrm{P}$-type MORB; $\mathrm{D}=\mathrm{NMORB} ; \mathrm{C}, \mathrm{D}=$ Volcanic arc basalts; d La/10-Y/15-Nb/8 diagram (Cabanis and Lecolle 1989) for discrimination of the tectonic setting; e Geotectonic diagram for (ultra-) basic rocks (Agrawal et al. 2008), IAB island arc basalt, $O I B$ oceanic island basalt; f MORB (Dilek and Furnes 2011) normalized spider plot diagram of the REE elements. Even though the under-ore breccia is significantly diluted by carbonate clasts, the pattern of the bauxite is still clearly visible
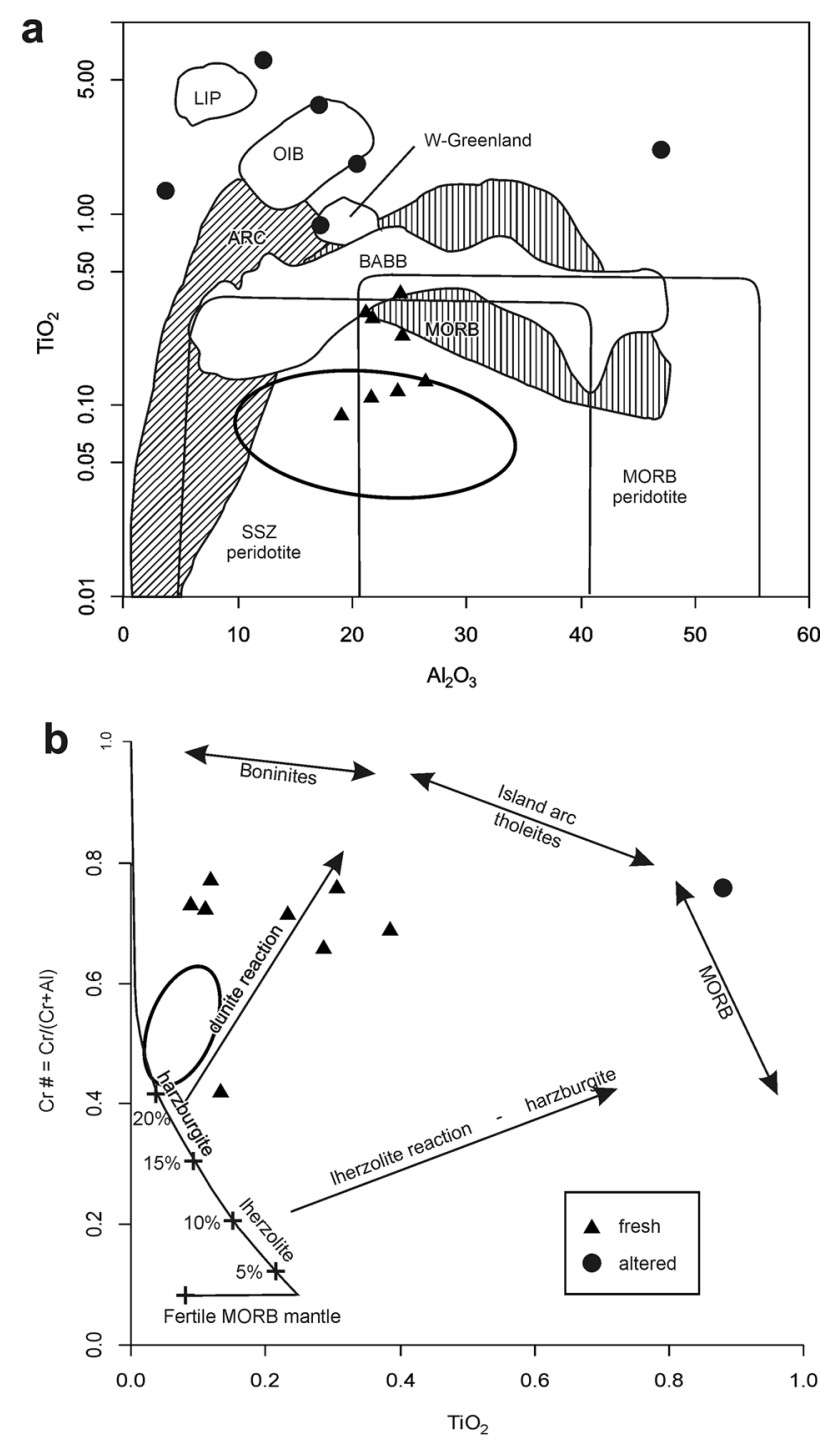

Fig. 10 a Chromite provenance diagram (modified from Kamenetsky et al. 2001), LIP large igneous province, OIB ocean-island basalt, $A R C$ island arc, $B A B B$ back-arc spreading; $\mathbf{b}$ chromite discrimination diagram of Pearce et al. (2000)
Similarities to the spinels found in the Kimmeridgian of the Sillenkopf basin (Gawlick et al. 2015) are outlined in Fig. 9a, b (red ellipses). Also, the assemblage of microfossils is remarkably similar; for instance, Crescentiella morronensis is rare in other time equivalent platforms and typical for the slope of the southern Lärchberg Carbonate Platform. Therefore, it is highly plausible that the Sillenkopf basin received material not only from the Lärchberg Carbonate Platform but also from the platform formed on top of the ophiolitic nappe stack and examined in this study (Fig. 10b).

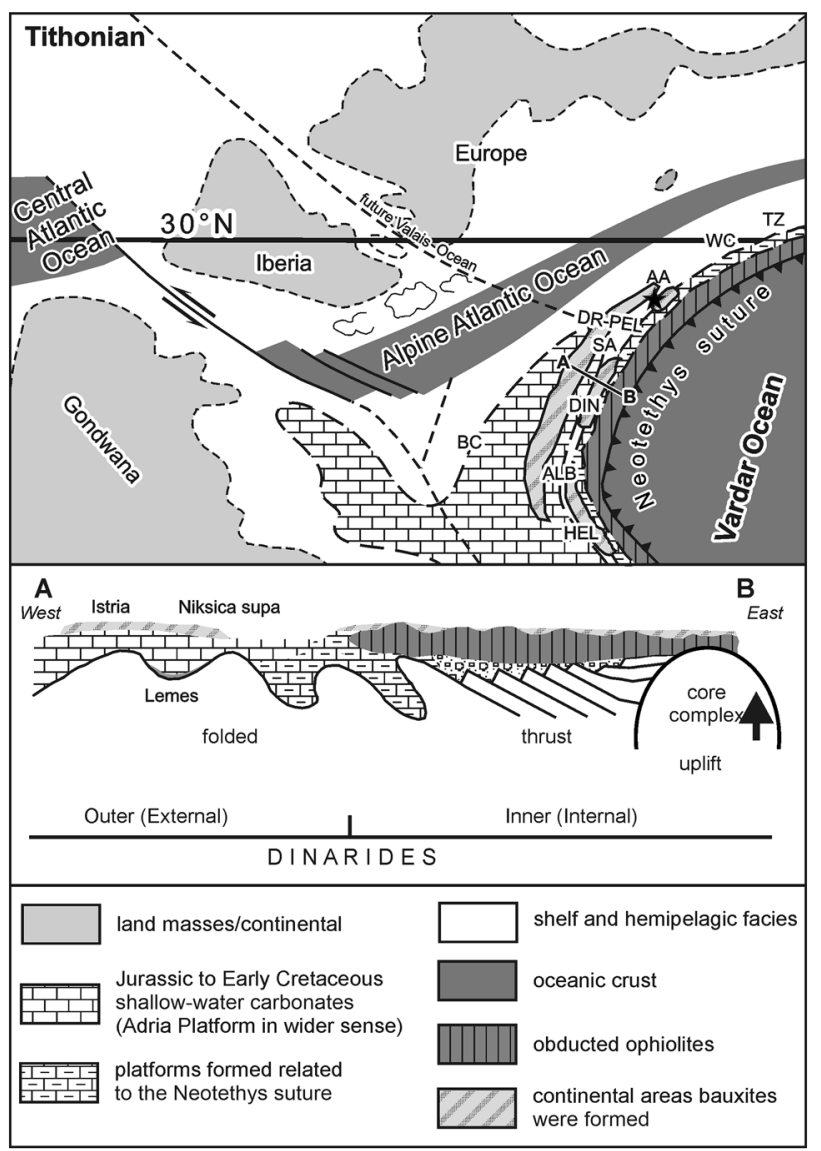

Fig. 11 Model for the formation of the Lugberg bauxite (indicated by the star): Bauxite formation in the fold-and-thrust belt of the Dinarides in the Tithonian. Uplift of the core complex from the Kimmeridgian/Tithonian boundary resulted in unroofing, further westward transport of the obducted ophiolites, and propagating deformation of the already slightly folded Outer Dinarides with bauxite formation in emerged areas. Paleogeographic reconstruction and crosssection modified from Gawlick and Missoni (2019), including results from Vlahović et al. (2005), Picotti and Cobianchi (2017), Gawlick et al. (2020). Bauxites of ?Kimmeridgian-Tithonian age from Grubić (1963), Mindszenty et al. (1995), Meço and Aliaj (2000), Timotijević (2001), Marković (2002), Mindszenty and D’Argenio (2002), Janković et al. (2003), Pajović and Radusinović (2012), Pajović et al. (2017) 
NNW

SSE

e Late Tithonian

continued subsidence and growth

of the carbonate platform

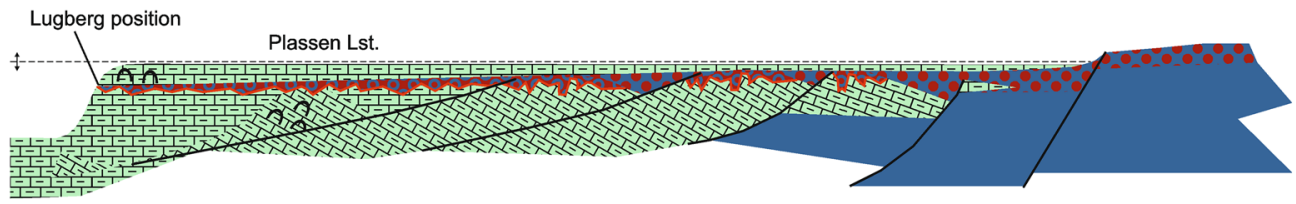

\section{d Tithonian}

unroofing and extension
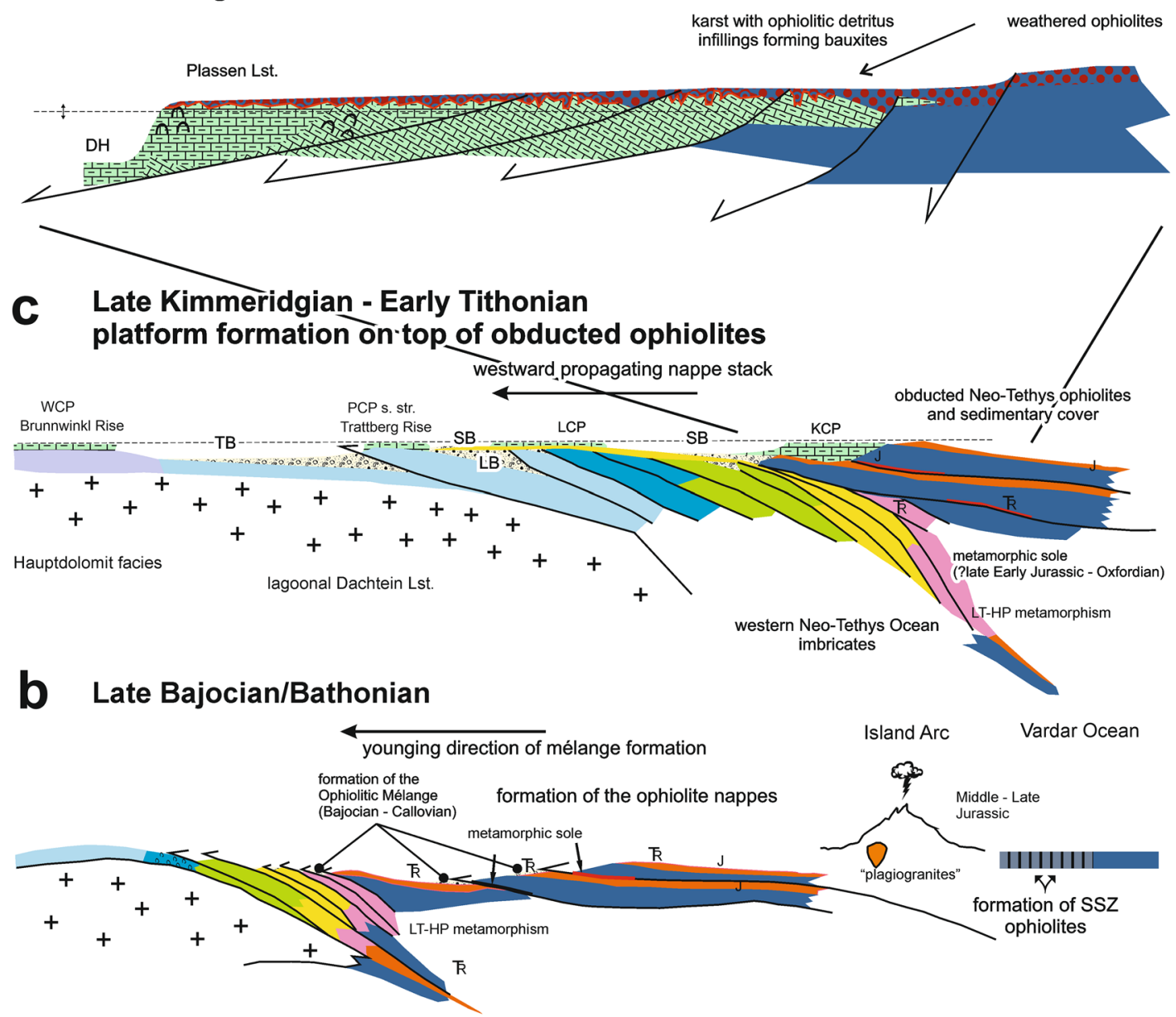

a Middle Triassic - Early Jurassic wider passive margin configuration

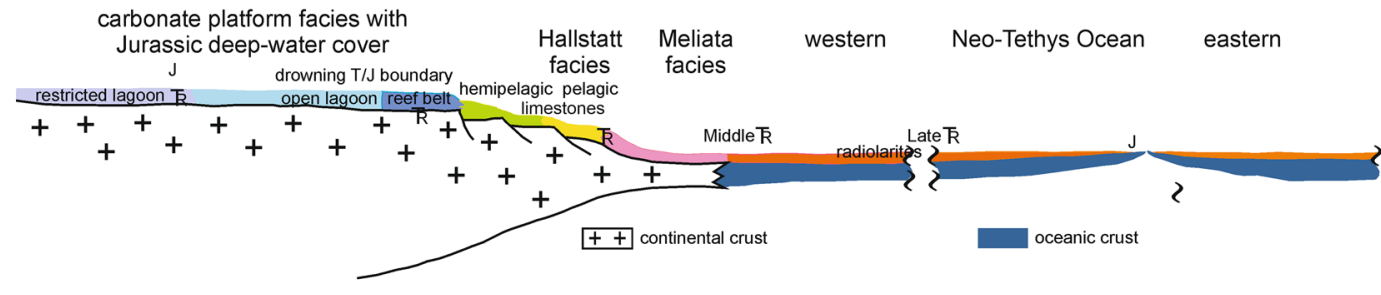


4Fig. 12 Tectonic sketch of the evolution of the Neo-Tethys throughout the Jurassic modified from Gawlick and Missoni (2019) and Missoni and Gawlick (2011a,b). WCP Wolfgangsee Carbonate Platform, $T B$ Tauglboden Basin, $P C P$ s.str. Plassen Carbonate Platform s.str., $S B$ Sillenkopf Basin, $L C P$ Lärchberg Carbonate Platform, $K C P$ Kurbnesh type Carbonate Platform, $D H$ Dietrichshorn position (Gawlick et al. 2015); a Middle Triassic to Early Jurassic: wider passive margin configuration bearing various facies belts; b Late Bajocian/Bathonian: interoceanic subduction and northwest directed thrusting leading to the formation of arc volcanites; $\mathbf{c}$ Late Kimmeridgian to Early Tithonian: thrusting reaches the continental crust in the northeast, formation of carbonate platforms on geographically higher nappes; d Tithonian: unroofing and extension leading to block tilting, local uplift, shedding of weathered ophiolitic material on the carbonate platforms, and formation of bauxites; e Late Tithonian: continuing subsidence and growth of the carbonate platforms

Its unique features differentiate the Lugberg bauxite clearly from other well-known Tithonian bauxites in the wider Adriatic plate, i.e., the bauxites in Istria or the Dinara Mt. region (Marković 2002) in Croatia or the main bauxite belt in Montenegro (Janković et al. 2003; Pajović et al. 2017). Theories for the source material for these bauxites range from weathering of clays or even limestones (Marković 2002, and references therein) to aeolian transported material (Pajović 2000, 2009). These bauxites most probably formed on anticlines developed in the frame of Middle to early Late Jurassic west-directed ophiolite obduction. Related to the overriding ophiolites the wider Adria plate attained a lower plate position and a thrust-and-fold belt established. Whereas the Inner Dinarides are characterized by a Middle-Late Jurassic nappe stack, ophiolite obduction affected the Outer Dinarides by folding and creation of syn- and anticlines (Fig. 11). An alternative model interpreted these effects as far-field compression (Picotti and Cobianchi 2017) related to ongoing west-directed transport of overriding ophiolites onto wider Adria. Bulging of the External Dinarides in Late Jurassic (Kimmeridgian) times as an alternative model (Durn 2003) for uplift and bauxite formation as proposed for various Mesozoic bauxites in the Circum-Pannonian region (D'Argenio and Mindszenty 1995; Mindszenty et al. 1995) can be excluded as the uplift was induced by the westward transported nappe stack, including the obducted ophiolites. (Fig. 12).

\section{Conclusions}

At Mount Lugberg in the Northern Calcareous Alps, bauxite is hosted by Late Kimmeridgian-Early Tithonian platform carbonates. Based on the results of the analysis of these bauxites and included heavy minerals it can be concluded that:
- The obducted Neo-Tethys ophiolites are the parent material of this Early Tithonian bauxite in the Northern Calcareous Alps; the bauxite can be classified as parautochthonous to allochthonous.

- Bauxite formed from an andesitic to basaltic parent material originating in a supra-subduction zone/island arc setting with some input of higher fractionated rocks formed in the island arc. The geochemical results are comparable with obducted Jurassic ophiolites known in the Dinarides/Albanides/Hellenides (Bortolotti et al. 2013; Dilek and Furnes 2009; Dilek et al 2007, 2008; Furnes et al. 2020; Koller et al. 2006; Hoeck et al. 2002; Robertson et al. 2009; Saccani et al. 2008, 2015).

- Deep weathering and erosion of the ophiolites and the overlying platform carbonates was triggered by an orogenic collapse with uplift and unroofing, which caused block-tilting and angular unconformities in the platform evolution. Block-tilting provided the accommodation space for the accumulation and bauxitization of the weathered ophiolites. Their weathered debris was transported fluviatile on subaerially exposed platform sectors.

- Rapid subsidence in the frame of ongoing extension caused a transgressive carbonate cycle shortly after bauxite formation.

Early Tithonian bauxite formation due to uplift of the Neotethyan Belt proves that ophiolite obduction onto the former wider Adria shelf started in the Middle Jurassic (Gawlick and Missoni 2019 and references therein) and not in the latest Jurassic or around the Jurassic/Cretaceous boundary as proposed by Schmid et al. (2020 and references therein).

Acknowledgements In the frame of REEBAUX (a RIS-project granted by EIT and EIT RawMaterials). Careful reviews of Andrea Mindszenty (Budapest) and Roman Aubrecht (Bratislava) are gratefully acknowledged.

Funding Open access funding provided by Montanuniversität Leoben.

Open Access This article is licensed under a Creative Commons Attribution 4.0 International License, which permits use, sharing, adaptation, distribution and reproduction in any medium or format, as long as you give appropriate credit to the original author(s) and the source, provide a link to the Creative Commons licence, and indicate if changes were made. The images or other third party material in this article are included in the article's Creative Commons licence, unless indicated otherwise in a credit line to the material. If material is not included in the article's Creative Commons licence and your intended use is not permitted by statutory regulation or exceeds the permitted use, you will need to obtain permission directly from the copyright holder. To view a copy of this licence, visit http://creativecommons.org/licenses/by/4.0/. 


\section{References}

Agrawal S, Guevara M, Verma SP (2008) Tectonic discrimination of basic and ultrabasic volcanic rocks through log-transformed ratios of immobile trace elements. Int Geol Rev 50:1057-1079. https:// doi.org/10.2747/0020-6814.50.12.1057

Auer M, Gawlick H-J, Suzuki H, Schlagintweit F (2009) Spatial and temporal development of siliceous basin and shallow-water carbonate sedimentation in Oxfordian Northern Calcareous Alps. Facies 55:63-87. https://doi.org/10.1007/s10347-008-0155-3

Auer M, Schlagintweit F, Gawlick H-J (2010) The Drei Brüder klippen structure - part of the major Trisselwand allochthon unit (Salzkammergut/central Northern Calcareous Alps). J Alpine Geol $52: 84-85$

Bárdossy G (1982) Karst bauxites. Elsevier, Amsterdam

Bárdossy G, Aleva GJJ (1990) Lateritic bauxites. Akadémiai Kiadó, Budapest, $\mathrm{p} 648$

Blatt H (1967) Provenance determinations and recycling of sediments. J Sediment Res 37:1031-1044

Bortolotti V, Chiari M, Marroni M, Pandolfi L, Principi G, Saccani E (2013) Geodynamic evolution of ophiolites from Albania and Greece (Dinaric-Hellenic belt): one, two, or more oceanic basins? Int J Earth Sci (geol Rundsch) 102:783-811. https://doi.org/10. 1007/s00531-012-0835-7

Boulègue J, Benedetti M, Bildgen P (1989) Geochemistry of waters associated with current karst bauxite formation, southern peninsula of Haiti. Appl Geochem 4:37-47. https://doi.org/10.1016/ 0883-2927(89)90057-7

Cabanis B, Lecolle M (1989) Le diagramme La/10-Y/15-Nb/8: un outil pour la discrimination des séries volcaniques et la mise en évidence des processus de mélange et/ou de contamination crustale. Comptes rendus de l'Académie des sciences Série 2. Mécanique Physique Chimie Sci De L'univers Sci De La Terre 309:2023-2029

Carras N, Fazzuoli M, Photiades A (2004) Transition from carbonate platform to pelagic deposition (Mid Jurassic-Late Cretaceous), Vourinos massif, northern Greece. Riv Ital Paleontol Stratigr 110:345-355

Combes P-J, Bárdossy G (1996) Geodynamics of Bauxites in the Tethyan Realm. In: Nairn AEM, Ricou L-E, Vrielynck B, Dercourt J (eds) The Tethys ocean. Springer, Boston, pp 347-365

D’Argenio B, Mindszenty A (1995) Bauxites and related paleokarst: tectonic and climatic event markers at regional unconformities. Eclogae Geol Helv 88:453-500

Dilek Y, Furnes H (2009) Structure and geochemistry of Tethyan ophiolites and their petrogenesis in subduction rollback systems. Lithos 113:1-20. https://doi.org/10.1016/j.lithos.2009.04.022

Dilek Y, Furnes H (2011) Ophiolite genesis and global tectonics: Geochemical and tectonic fingerprinting of ancient oceanic lithosphere. GSA Bull 123:387-411. https://doi.org/10.1130/ B30446.1

Dilek Y, Furnes H, Shallo M (2007) Suprasubduction zone ophiolite formation along the periphery of Mesozoic Gondwana. Gondwana Res 11:453-475. https://doi.org/10.1016/j.gr.2007.01.005

Dilek Y, Furnes H, Shallo M (2008) Geochemistry of the Jurassic Mirdita Ophiolite (Albania) and the MORB to SSZ evolution of a marginal basin oceanic crust. Lithos 100:174-209

Durn G (2003) Jurassic and palaeogene bauxites. In: Field trip guidebook of the 22nd IAS meeting of sedimentology. Opatija, Zagreb, pp 209-254

Frisch W, Gawlick H-J (2003) The nappe structure of the central Northern Calcareous Alps and its disintegration during Miocene tectonic extrusion: a contribution to understanding the orogenic evolution of the Eastern Alps. Int J Earth Sci 92:712-727. https:// doi.org/10.1007/s00531-003-0357-4
Furnes H, Dilek Y, Zhao G, Safonova I, Santosh M (2020) Geochemical characterization of ophiolites in the Alpine-Himalayan Orogenic Belt: magmatically and tectonically diverse evolution of the Mesozoic Neotethyan oceanic crust. Earth-Sci Rev 208:103258

Gawlick H-J, Missoni S (2019) Middle-Late Jurassic sedimentary mélange formation related to ophiolite obduction in the Alpine-Carpathian-Dinaridic Mountain Range. Gondwana Res $74: 144-172$

Gawlick H-J, Schlagintweit F (2006) Berriasian drowning of the Plassen carbonate platform at the type-locality and its bearing on the early Eoalpine orogenic dynamics in the Northern Calcareous Alps (Austria). Int J Earth Sci (geol Rundsch) 95:451-462. https:// doi.org/10.1007/s00531-005-0048-4

Gawlick H-J, Krystyn L, Lein R (1994) Conodont colour alteration indices: Palaeotemperatures and metamorphism in the Northern Calcareous Alps: a general view. Geol Rundsch 83:660-664

Gawlick H-J, Frisch W, Vecsei A, Steiger T, Böhm F (1999a) The change from rifting to thrusting in the Northern Calcareous Alps as recorded in Jurassic sediments. Geol Rundsch 87:644-657

Gawlick HJ, Suzuki H, Vortisch W, Wegerer E (1999b) Zur stratigraphischen Stellung der Tauglbodenschichten an der Typlokalität in der Osterhorngruppe (Nördliche Kalkalpen, Ober-OxfordiumUnter-Tithonium). Mitteilungen Ges Geol Bergbaustud Österr 42:1-20. https://doi.org/10.1016/j.gr.2019.03.003

Gawlick HJ, Schlagintweit F, Missoni S (2007) Das Ober-Jura Seichtwasser-Karbonat-Vorkommen der Drei Brüder am Wolfgangsee (Salzkammergut, Österreich): das westlichste Vorkommen der Wolfgangsee-Karbonatplattform südlich der BrunnwinklSchwelle am Nordrand des Tauglboden-Beckens. Mitt Ges Geol Bergbaustud Österr 48:83-100

Gawlick H-J, Frisch W, Hoxha L, Dumitrica P, Krystyn L, Lein R, Missoni S, Schlagintweit F (2008) Mirdita Zone ophiolites and associated sediments in Albania reveal Neotethys Ocean origin. Int J Earth Sci 97:865. https://doi.org/10.1007/s00531-007-0193-Z

Gawlick H, Missoni S, Schlagintweit F, Suzuki H, Frisch W, Krystyn L, Blau J, Lein R (2009) Jurassic Tectonostratigraphy of the Austroalpine domain. J Alpine Geol 50:1-152

Gawlick H-J, Missoni S, Schlagintweit F, Suzuki H (2012) Jurassic active continental margin deep-water basin and carbonate platform formation in the northwestern Tethyan realm (Austria, Germany). J Alpine Geol 54:189-291

Gawlick H-J, Aubrecht R, Schlagintweit F, Missoni S, Plašienka D (2015) Ophiolitic detritus in Kimmeridgian resedimented limestones and its provenance from an eroded obducted ophiolitic nappe stack south of the Northern Calcareous Alps (Austria). Geol Carpath 66:473-487. https://doi.org/10.1515/ geoca-2015-0039

Gawlick H-J, Sudar M, Missoni S, Aubrecht R, Schlagintweit F, Jovanović D, Mikuš T (2020) Formation of a Late Jurassic carbonate platform on top of the obducted Dinaridic ophiolites deduced from the analysis of carbonate pebbles and ophiolitic detritus in southwestern Serbia. Int J Earth Sci 109:2023-2048. https://doi. org/10.1007/s00531-020-01886-w

Grubić A (1963) The stratigraphic position of bauxites in Yugoslav Dinarides yougoslaves. ICSOBA, Zagreb 1:51-79

Hoeck V, Koller F, Meisel T, Onuzi K, Kneringer E (2002) The Jurassic South Albanian ophiolites: MOR-vs. SSZ-Type Ophiolites Lithos 65:143-164

Janković S, Jelenković R, Vujić S (2003) Mineral resources and potential prognosis of metallic and non-metallic mineral raw materials in Serbia and Montenegro at the end of the XX Century. Engineering Academy of Serbia and Montenegro, Beograd

Janoušek V, Farrow CM, Erban V (2006) Interpretation of whole-rock geochemical data in igneous geochemistry: introducing geochemical data toolkit (GCDkit). J Pet 47:1255-1259. https://doi.org/10. 1093/petrology/eg1013 
Johnson C (2012) Podiform chromite at Voskhod, Kazakhstan. PhD Thesis, Cardiff University, Cardiff, p 449

Kamenetsky VS, Crawford AJ, Meffre S (2001) Factors controlling chemistry of magmatic spinel: an empirical study of associated olivine, Cr-spinel and Melt Inclusions from primitive rocks. J Petrol 42:655-671. https://doi.org/10.1093/petrology/42.4.655

Kelemen P, Dunkl I, Csillag G, Mindszenty A, von Eynatten H, Józsa S (2017) Tracing multiple resedimentation on an isolated karstified plateau: the bauxite-bearing Miocene red clay of the Southern Bakony Mountains, Hungary. Sed Geol 358:84-96. https://doi. org/10.1016/j.sedgeo.2017.07.005

Koller F, Höck V, Meisel T, Ionescu C, Onuzi K, Ghega D (2006) Cumulates and gabbros in southern Albanian ophiolites: their bearing on regional tectonic setting. Geol Soc Lond Spec Publ 260:267-299

Krische O, Goričan Š, Gawlick H-J (2014) Erosion of a Jurassic ophiolitic nappe-stack as indicated by exotic components in the Lower Cretaceous Rossfeld Formation of the Northern Calcareous Alps (Austria). Geol Carpath 65:3-24. https://doi.org/10.2478/ geoca-2014-0001

Lein R (1985) Das Mesozoikum der Nördlichen Kalkalpen als Beispiel eines gerichteten Sedimentationsverlaufes infolge fortschreitender Krustenausdünnung. Archiv Lagerstättenforschung Geol Bundesanstalt 6:117-128

Leitner C, Neubauer F, Genser J, Borojević-Šoštarić S, Rantitsch G (2014) 40Ar/39Ar ages of crystallization and recrystallization of rock-forming polyhalite in Alpine rocksalt deposits. Geol Soc Lond Spec Publ 378:207-224. https://doi.org/10.1144/SP378.5

Lewis D, McConchine D (1994) Practical Sedimentology. Chapman and Hall, New York

Marković S (2002) Hrvatske mineralne sirovine. Institut za geološka istraživanja, Zavod za geologiju, Zagreb, p 544

Meço S, Aliaj S (2000) Geology of Albania. Gebrüder Borntraeger, Berlin

Meschede M (1986) A method of discriminating between different types of mid-ocean ridge basalts and continental tholeiites with the Nb-Zr-Y diagram. Chem Geol 56:207-218

Mindszenty A, D'Argenio B (2002) Jurassic bauxites recording uplift and emergence of tectonically influenced carbonate platform sectors in the Western Tethyan Realm. In: VI International Symposium on the Jurassic System. Palermo

Mindszenty A, D’Argenio B, Aiello G (1995) Lithospheric bulges recorded by regional unconformities. The Case of MesozoicTertiary Apulia. Tectonophysics 252:137-161

Mindszenty A, Ottner F, Lobitzer H (2005) The Bauxite occurrence of Russbach-Almweg near Strobl, Upper Austria. Gmundnder GeoStudien 3:47-50

Missoni S, Gawlick H-J (2011a) Evidence for Jurassic subduction from the Northern Calcareous Alps (Berchtesgaden; Austroalpine, Germany). Int J Earth Sci 100:1605-1631. https://doi.org/10.1007/ s00531-010-0552-z

Missoni S, Gawlick H-J (2011b) Jurassic mountain building and Mesozoic-Cenozoic geodynamic evolution of the Northern Calcareous Alps as proven in the Berchtesgaden Alps (Germany). Facies 57:137-186. https://doi.org/10.1007/s10347-010-0225-1

Muhs DR, Budahn JR, Prospero JM, Skipp G, Herwitz SR (2012) Soil genesis on the island of Bermuda in the Quaternary: the importance of African dust transport and deposition. J Geophys Res 117:F03025. https://doi.org/10.1029/2012JF002366

Neubauer F, Genser J, Handler R (2000) The Eastern Alps: result of a two-stage collision process. Mitteilungen Der Österreichischen Geologischen Gesellschaft 92:117-134

Ohta T, Arai H (2007) Statistical empirical index of chemical weathering in igneous rocks: a new tool for evaluating the degree of weathering. Chem Geol 240:280-297. https://doi.org/10.1016/j. chemgeo.2007.02.017
Pajović M (2000) Genetic model of the karstic bauxites in the dinarides. In: Karamata S, Jankovic S (eds) Proceedings of the International Symposium Geology and Metallogeny of the Dinarides and the Vardar Zone. Academy of Sciences and Arts of The Republic of Srpska, Banja Luka, p 537

Pajović M (2009) Genesis and genetic types of karst bauxites. Iran J Earth Sci 1:44-56

Pajović M, Radusinović S (2012) Methods for Production of Metallogenic-Prognostic Map of Red Karst Bauxite in the Region of Nikšićka Župa, Montenegro (Europe). Iran J Earth Sci 4:12-20

Pajović M, Mirković M, Svrkota R, Ilić D, Radusinović S (2017) Geologija boksitonosnog rejona Vojnik-Maganik (Crna Gora)/ Geology of the Vojnik-Maganik baxite-bearing region (Montenegro). In: Separate issues of the Geological Bulletin, vol XXI. Geological Survey of Montenegro, pp 1-431

Pearce JA (1996) A user's guide to basalt discrimination diagrams trace element geochemistry of volcanic rocks: applications for massive sulphide exploration Geological Association of Canada. Short Course Notes 12:79-113

Pearce JA, Barker PF, Edwards SJ, Parkinson IJ, Leat PT (2000) Geochemistry and tectonic significance of peridotites from the South Sandwich arc-basin system, South Atlantic. Contrib Miner Petrol 139:36-53. https://doi.org/10.1007/s004100050572

Picotti V, Cobianchi M (2017) Jurassic stratigraphy of the Belluno Basin and Friuli Platform: a perspective on far-field compression in the Adria passive margin. Swiss J Geosci 110:833-850. https:// doi.org/10.1007/s00015-017-0280-5

Plöchinger B (1964) Bericht über die Klippen-Flyschfenster von St. Gilgen und Strobl am Wolfgangsee. Veröffentlichungen Aus Dem Haus Der Natur in Salzburg 15:12-17

Robertson A, Karamata S, Šarić K (2009) Overview of ophiolites and related units in the Late Palaeozoic-Early Cenozoic magmatic and tectonic development of Tethys in the northern part of the Balkan region. Lithos 108:1-36. https://doi.org/10.1016/j.lithos. 2008.09.007

Saccani E, Bortolotti V, Marroni M, Pandolfi L, Photiades A, Principi G (2008) The Jurassic association of backarc basin ophiolites and calc-alkaline volcanics in the Guevgueli Complex (Northern Greece): implication for the evolution of the Vardar Zone. Ofioliti 33:209-227

Saccani E, Dilek Y, Marroni M, Pandolfi L (2015) Continental margin ophiolites of Neotethys: remnants of ancient Ocean-Continent Transition Zone (OCTZ) Lithosphere and their geochemistry, mantle sources and melt evolution patterns. Episodes 38(4):230-249

Schadler J (1948) Ein neues Bauxit-Vorkommen in Oberösterreich. (Rußbach bei Strobl am Wolfgangsee). Verhandlungen der Geologischen Bundesanstalt:136-137

Schindelin J, Arganda-Carreras I, Frise E, Kaynig V, Longair M, Pietzsch T, Preibisch S, Rueden C, Saalfeld S, Schmid B (2012) Fiji: an open-source platform for biological-image analysis. Nat Methods 9:676-682. https://doi.org/10.1038/nmeth.2019

Schlagintweit F (2011) The dasycladalean algae of the Plassen Carbonate Platform (Kimmeridgian-Early Berriasian) and the Barmstein Limestone (Late Tithonian): taxonomic inventory and palaeogeographical implications within the platform-basin-system of the Northern Calcareous Alps. Geologia Croatica 64(3):185-206. https://doi.org/10.4154/GC.2011.16

Schlagintweit F, Gawlick HJ, Ebli O, Rünstler H, Suzuki H (2003) Die Plassen-Formation (Kimmeridgium) des Krahstein, Steirisches Salzkammergut und deren Unterlagerung: Neue Daten zur Fazies, Biostratigraphie und Sedimentologie [The Plassen Formation, Kimmeridgian, of the Krahstein, Styrian Salzkammergut, and its basement: new data on facies, biostratigraphy and sedimentology-in German]. Beiträge Zur Geologie Des Salzkammergutes Gmundner Geo-Studien 2:87-96 
Schlagintweit F, Gawlick H-J, Lein R (2005) Mikropaläontologie und Biostratigraphie der Plassen-Karbonatplattform der Typlokalität (Ober-Jura bis Unter-Kreide, Salzkammergut, Österreich). J Alpine Geol 47:11-102

Schlagintweit F, Gawlick H-J, Missoni S, Hoxha L, Lein R, Frisch W (2008) The eroded Late Jurassic Kurbnesh carbonate platform in the Mirdita Ophiolite Zone of Albania and its bearing on the Jurassic orogeny of the Neotethys realm. Swiss J Geosci 101:125138. https://doi.org/10.1007/s00015-008-1254-4

Schmid SM, Bernoulli D, Fügenschuh B, Matenco L, Schefer S, Schuster R, Tischler M, Ustaszewski K (2008) The Alpine-CarpathianDinaridic orogenic system: correlation and evolution of tectonic units. Swiss J Geosci 101:139-183. https://doi.org/10.1007/ s00015-008-1247-3

Schmid SM, Fügenschuh B, Kounov A, Matenco L, Nievergelt P, Oberhänsli R, Pleuger J, Schefer S, Schuster R, Tomljenović B (2020) Tectonic units of the Alpine collision zone between Eastern Alps and Western Turkey. Gondwana Res 78:308-374. https://doi.org/ 10.1016/j.gr.2019.07.005
Timotijević S (2001) Kredni Boksiti Srbije Cretaceous bauxites of Serbia. Geoinstitut, Beograd

Tollmann A (1977) Geologie von Österreich: Die Zentralalpen. Deuticke, Wien, p 766

Tollmann A (1985) Geologie von Österreich: Außerzentralalpiner Teil. Deuticke, Wien, p 710

Tollmann A (1986) Geologie von Österreich: Gesamtübersicht. Deuticke, Wien, p 718

Valeton I (1972) Bauxites. Elsevier, Amsterdam, p 226

Vlahović I, Tišljar J, Velić I, Matičec D (2005) Evolution of the Adriatic Carbonate Platform: Palaeogeography, main events and depositional dynamics. Palaeogeogr Palaeoclimatol Palaeoecol 220:333-360. https://doi.org/10.1016/j.palaeo.2005.01.011

Winchester JA, Floyd PA (1977) Geochemical discrimination of different magma series and their differentiation products using immobile elements. Chem Geol 20:325-343

Zuffa GG (1980) Hybrid arenites; their composition and classification. J Sediment Res 50:21-29 